\title{
1136. ジルコニウム水素化物および水素固溶体の機械的性質
}

\author{
山中 伸介 ${ }^{1, *}$, 黒田 雅利 ${ }^{1}$, 瀬戸山 大吾1 \\ Mechanical Properties of Zirconium Hydride and Hydrogen Solid Solution \\ Shinsuke YAMANAKA, Masatoshi KURODA and Daigo SETOYAMA
}

\begin{abstract}
In the present study, such mechanical properties of hydrogenated zirconium as sound velocities, elastic moduli, hardness and stress-strain curve have been evaluated by ultrasonic pulse-echo method, Vickers hardness test, tensile test and resonance method using cantilever beam specimens, and the influence of the hydrogen uptake on the mechanical properties of zirconium alloys has been studied. The elastic moduli of solid zirconium hydride estimated from the sound velocities were larger than that of pure zirconium metal, and slightly depended on the hydrogen content. The hardness of the solid zirconium hydride was much higher than that of the pure zirconium, and decreased with increasing the hydrogen content. The Young's modulus of the solid zirconium hydride obtained from the tensile tests was in good agreement with the value estimated from the sound velocities. The elastic moduli of hydrogen solid solution obtained by the resonance method decreased with the hydrogen content. The elastic moduli of partially precipitated hydride were also measured by the resonance method, and the results could be elucidated from the datum of the elastic moduli of the solid zirconium hydride and the hydride solid solution obtained in the present study.
\end{abstract}

KEYWORDS: mechanical properties, Zircaloy, zirconium hydrides, hydrogen solid solution, sound velocity, elastic modulus, hardness, stress-strain curve, ultrasonic pulse-echo method, resonance method

\section{I. 緒 言}

近年, 軽水炉燃料の高燃焼度化に伴い, 炉内滞在時間が 長期化し，ジルカロイ被覆管の水側腐食量が増大すること が問題視されている。ジルコニウム $(\mathrm{Zr})$ 合金は，次式で 表される腐食反応により，二酸化ジルコニウムと水素を発 生する。

$$
\mathrm{Zr}+2 \mathrm{H}_{2} \mathrm{O} \longrightarrow \mathrm{ZrO}_{2}+2 \mathrm{H}_{2}
$$

この腐食反応に伴って発生する水素の一定割合 $(10 \sim 20$ \%)が，ジルカロイ被覆管中に吸収される。一般に水素の $\mathrm{Zr}$ への固溶限は，室温では極めて低く 0.1 wtppm 以下で ある1。固溶限を越える水素量は，ジコニウム水素化物 としてジルカロイ被覆管中に析出する。この析出氷素化物 は, 被覆管の延性や強度低下に強く関与することが報告さ れており 2 6), 被覆管の健全性を維持するためには, ジル コニウム水素化物の物性を十分に把握しておくことが重要 であると考えられる。一方, 温度が上昇するのに伴い，

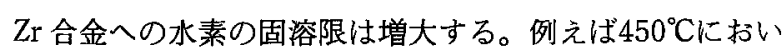
ては，約 $120 \mathrm{wtppm}$ の水素が Zr 合金に固溶すると報告さ れている1)。これまでの報告によると, 運転温度で水素が すべて固溶していれば，水素脆化の観点からは，被覆管の 健全性にほとんど問題がないとされている7)。しかしなが ら近年, ジルカロイ被覆管中に固溶した水素がクリープ速

1 大阪大学大学院工学研究科原子力工学専攻 (Dept. of Nucl. Eng., Graduate School of Eng., Osaka Univ.) (2002年 5 月 15 日 受理；2002年 8 月 5 日 査読通過)

*著者連絡先 : Tel. 06-6879-7904, Fax. 06-6879-7889, E-mail: yamanaka@nucl.eng.osaka-u.ac.jp
度を増大させる可能性が指摘されるなど8)，高温時におけ る被覆管の健全性の観点から，ジルコニウム水素固溶体の 物性を評価する必要性が増してきている。以上のような背 景により本研究では, 次章に示すように, 水素化した $\mathrm{Zr}$ の様々な機械的性質を評価し，Zr 合金の物性に及ほす水 素吸収の影響を総合的に考察した。

\section{II. 研 究 概 要}

$\mathrm{Zr}$ 合金は, 水素吸収量の増大に伴い, Fig. 1 に示すよ うに，析出水素化物が存在せず水素がすべて Zr 中に固溶 している状態(以後, 水素固溶体と称す), 一部水素化物が 析出した状態(以後, 一部析出水素化物と称す), シルコニ ウム水素化物のバルク材 (以後, バルク水素化物と称す) と 相状態が変化する。特にバルク水素化物は，作製するのが 非常に困難であると報告されており9,10)，その物性測定に は極めて価值があるものと考えられる。著者らはそのバル ク水素化物の作製に成功し，これまでそのバルク水素化物 の音速, 弾性定数, 硬度, 応力ーひずみ線図などの機械的 性質を, 超音波パルスエコー法, ビッカース硬度試験, 静

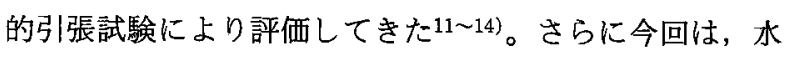
素固溶体扔よび一部析出水素化物の弾性定数を，片持ち式 固有振動法により評価した。これらの結果より， $\mathrm{Zr}$ の機 械的性質に与える水素吸収の影響を各相の機械的性質から 総合的に検討した。Fig. 2 に本研究の概要図を示す。

III. 実 験 方 法

1. 試 料

純 $\mathrm{r}$ は住友金属工業秼製の試料(不純物濃度 $0: 0.125$, 


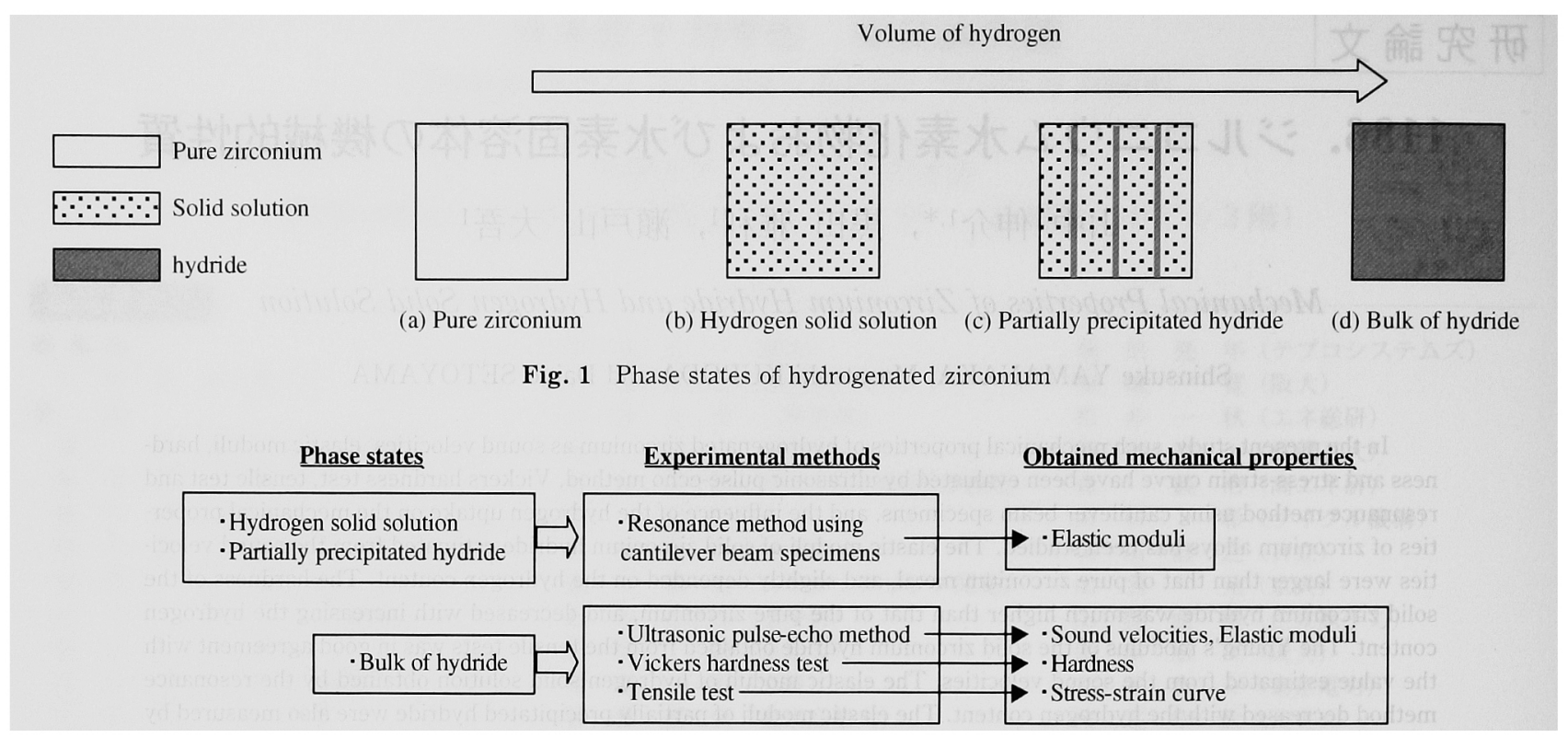

Fig. 2 Outline of the present study

$\mathrm{H}: 0.0006, \mathrm{~N}: 0.0024, \mathrm{C}: 0.003, \mathrm{Fe}: 0.006, \mathrm{Cr}: 0.008 \mathrm{wt} \%)$ を使用した。その試料を改良型ジーベルツ装置により，純 度 $99.999 \%$ の水素ガス䨌囲気の下，水素王を調整すること により，水素固溶体，一部析出水素化物およびバルク水素 化物を作製した。以下に，ジーベルツ装置および水素化の 手順の詳細を記述する。

改良型ジーベルツ装置は，反応系と水素ガス精製系から なる。反応系は，石英ガラス製反応管，玨力測定計，ガス だめから成り立っており, 液体窒素コールドトラップ付き 油拡散ポンプにより $10^{-6} \mathrm{~Pa}$ まで排気可能である。試料 は，モリブデン簿に入れ反応管内に装荷し，抵抗加熱炉を 用いて加熱した。試料温度は, PR 熱電対, サイリスタ温

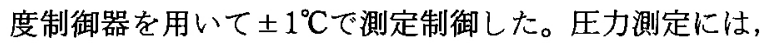
3 台のバラトロンキャパシタンスマノメータを使用した。 ガス精製系において，水素ガスを液体窒素トラップにより 精製した。水素化は，純 $\mathrm{Zr}$ を $10^{-6} \mathrm{~Pa}$ の真空中において $800^{\circ} \mathrm{C}$ で脱ガス処理並びに焼鈍を行った後, $700^{\circ} \mathrm{C} て ゙$ 所定 の圧力の水素ガスと接触させて行った。ただし, 水素濃度 $0 \mathrm{ppm}$ の試料については脱ガス処理のみを行った。平衡状 態に到達するまで十分時間をおいた後, 試料中の水素濃度 を評価し，バルク水素化物作製時は室温まで急冷，その他 は炉冷した。得られた水素化後の試料に対して，䏭堀場製 作所製の水素分析装置 EMGA-621 を用いて,より正確な 水素濃度を評価した。なお，バルク水素化物については X線回折測定により単相であることを確認した。

\section{2. 機械的性啠}

バルク水素化物の音速は，超音波パルスエコー法を用い て測定した。試料形状は直径 $6 \mathrm{~mm}$, 高さ $10 \mathrm{~mm}$ の円柱 状であった。超音波の送受信には， $5 \mathrm{MHz}$ のトランスジ
ユーサを用い，その計測制御には日本マテック社 Echometer1062を使用した。また，試料とトランスシューサと の接着にはソニコートSHN13を用いた。得られた音速よ り, 弾性定数の評価を行った。微小硬度測定は, 松沢精機 製のビッカース硬度試験器 MHT-1により実施した。測 定は, 荷重 $500 \mathrm{~g}, 30 \mathrm{~s}$ でそれぞれ 7 回実施し, 最高値と 最小值を除き平均值を求め, 硬度を評価した。並行して引 張試験も実施した。試料形状は, 長さ $24 \mathrm{~mm}$, 幅 10 $\mathrm{mm}$, 厚さ $1 \mathrm{~mm}$, 平行部長 $6.3 \mathrm{~mm}$ の平板引張試験片 で, 引張速度 $1 \mathrm{~mm} / \mathrm{min}$ で応力ーひずみ関係を得た。バル ク水素化物の物性測定のために作製された試料はいずれも 理論密度にほぼ等しい密度を持っていた。なおっこれらの 測定は前報11,13)においても紹介した。

水素固溶体および一部析出水素化物の弾性定数は, 日本 テクノプラス侏製高温弾性率等同時測定装置 EG-HTを 用いて，片持ち式固有振動法により測定した。試料形状 は, 厚さ $2 \mathrm{~mm}$, 幅 $10 \mathrm{~mm}$, 長さ $45 \mathrm{~mm}$ の板状であった。

\section{IV. 解析手法}

測定されたデータから，以下のような手法を用いて諸物 性を評価した。

バルク水素化物の上うな等方的な材料においては，縦波 および横波音速 $V_{l}, V_{s}$ から，材料の弾性定数(ヤング率 $E$, 剛性率 $G)$ を, 次式により求めることができる。

$$
\begin{aligned}
& E=G\left[\left(3 V_{l}^{2}-4 V_{s}^{2}\right) /\left(V_{l}^{2}-V_{s}^{2}\right)\right] \\
& G=\rho V_{s}^{2}
\end{aligned}
$$

ここで, $\rho$ は材料の密度である。

水素固溶体および一部析出水素化物に対しては, 片持ち 式固有振動法により, 以下の計算式を用いて弾性定数(ヤ ング率 $E$, 剛性率 $G$ )が求められる。 


$$
\begin{aligned}
& E=\omega^{2} \rho S / I \alpha_{4} \\
& G=\beta \omega^{2} / L
\end{aligned}
$$

ここで， $\omega$ は角振動数， $S$ は試料断面積，Iは試料の慣性 モーメント， $\alpha$ は横振動に対する装置変数， $\beta$ はねじり振 動に対する装置変数，Lはねじり剛性定数である。

\section{V. 結果および考察}

\section{1. バルク水素化物}

バルク水素化物中の音速は, 縦波, 横波とも純 $\mathrm{Zr}$ より 大きく，この音速測定データから室温における弾性定数を 評価した。Fig. $3^{11)}$ に示すように，バルク水素化物の弾性 定数(ヤング率 $E$, 剛性率 $G$ ) は, 純 $\operatorname{Zr}$ のそれに比べて大 きいことがわかる。また，同図に示すように，弾性定数の 水素濃度依存性は小さく，僅かながら水素濃度とともに減 少していく傾向が見られる。

微小硬度 $H_{r}$ 。を測定することにより材料の塑性的な性質 を評価することができる。バルク水素化物の微小硬度は， 純 $\mathrm{Zr}$ よりもかなり大きいことがわかった。バルク水素化 物の敞小硬度とヤング率の比を Fig. $4^{11}$ に示す。微小硬 度とヤング率の比 $H_{v} / E$ は，セラミックスについて約 0.05 という值が報告されており15!，純金属については，体心 立方構造 0.006 , 面心立方構造 0.003 , 六方最密充填構造 0.004 という值が文献值 ${ }^{16 !}$ 上り計算された。バルク水素化 物の $H_{v} / E$ 比は 0.02 という值が得られ，セラミックスと金 属の中間的性質を持っていることがわかった。

バルク水素化物の室温における静的引張試験を行った結 果, Fig. 5131に示すような応力ーひずみ曲線が得られた。 引張試験で得られたヤング率の值 $135.9 \mathrm{GPa}$ は, 超音波 音速測定から評価された値とよく一致していた。また，破 断応力として $18 \mathrm{MPa}$ が求められた。

\section{2. 水素固溶体}

片持ち式固有振動法により求めた水素固溶体および一部 析出水素化物のヤング率の, 水素濃度依存性および温度依
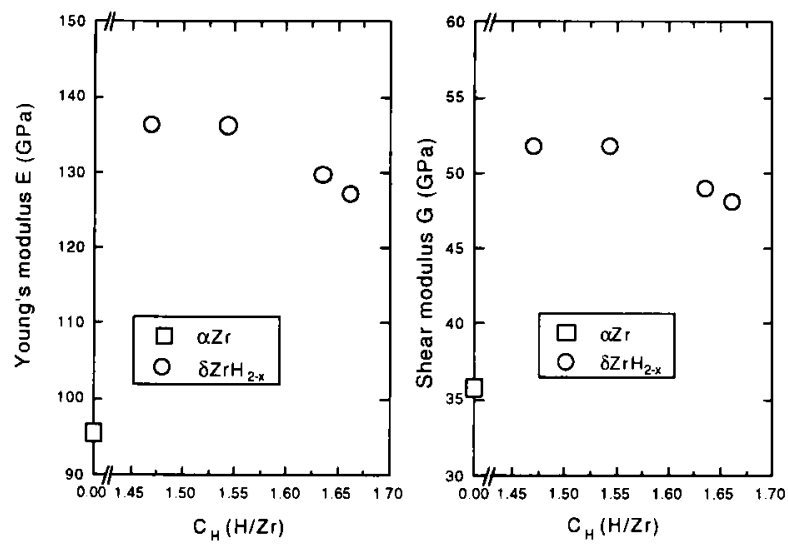

Fig. 3 Change in the Young's modulus $E$ and shear modulus $G$ of $\delta \mathrm{ZrH}_{2-x}$ with the hydrogen content $C_{\mathrm{H}^{11}}$
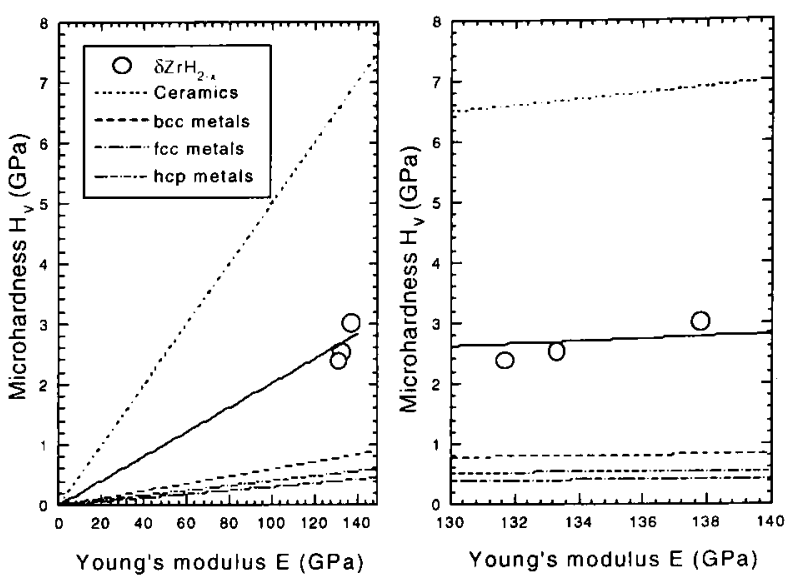

Fig. 4 Relationship between microhardness $H_{V}$ and Young's modulus $E$ for $\delta \mathrm{ZrH}_{2-x}{ }^{111}$

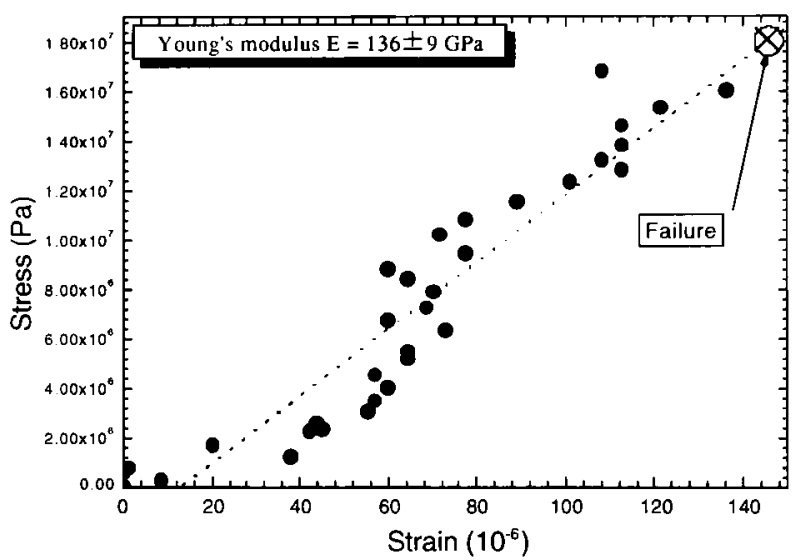

Fig. 5 Stress-strain curve of $\delta \mathrm{ZrH}_{1.73}{ }^{13)}$

存性の結果をそれぞれ Figs. 6, 7 に示す。図中, 塗りつ ぶされたプロットは水素固溶体，その他のプロットは一部 析出水素化物を表している。Fig. 6 の結果加ら, 水素固溶 体の試料では, 水素濃度の増大に伴いヤング率が減少して いるのに対し，固溶限を越えた一部析出水素化物の試料で は，水素濃度の增大に伴い，ヤング率が $130 \mathrm{ppm}$ 付近ま で若干增大する傾向が認められる。また Fig. 7 より，温 度上昇に伴い, 水素固溶体抢よび一部析出水素化物のヤン グ率が，両者とも減少していることがわかる。

Fig. 6 中，水素固溶体のプロットのみを取り出した結果 をFig. 8 に示す。同図より，水素濃度が増大するのに伴 い，ヤング率は直線的に低下し，その傾きは温度に依存せ ず一定になっているように見受けられる。そこで次に，そ の傾きに温度依存性があるのかどうかを詳細に検討するた めに，測定されたヤング率 $E$ と水素濃度か $0 \mathrm{ppm} の$ 際の

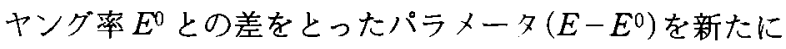
導入し，そのパラメータと水素濃度との関係を調べた。

Fig. 9 にそのパラメータ $\left(E-E^{0}\right)$ の水素濃度依存性を示 す。同図より，E-E $E^{0}$ と水素濃度 $C_{\mathrm{H}}$ との間には，温度に 


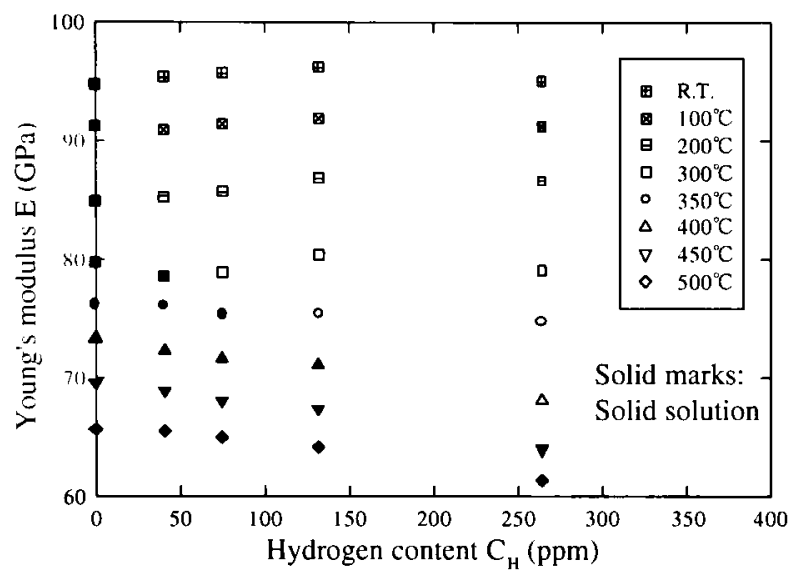

Fig. 6 Change in the Young's modulus $E$ of hydrogenated zirconium with the hydrogen content $C_{H}$

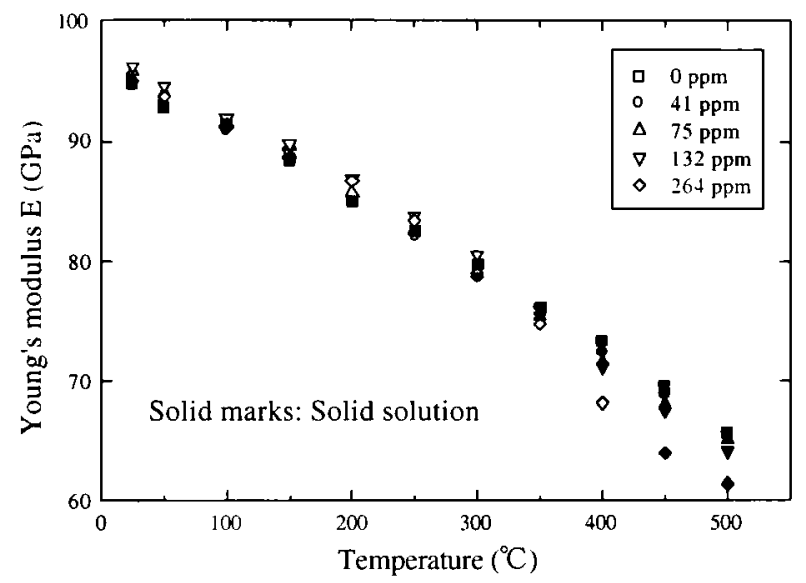

Fig. 7 Temperature dependence of Young's modulus $E$ of hydrogenated zirconium

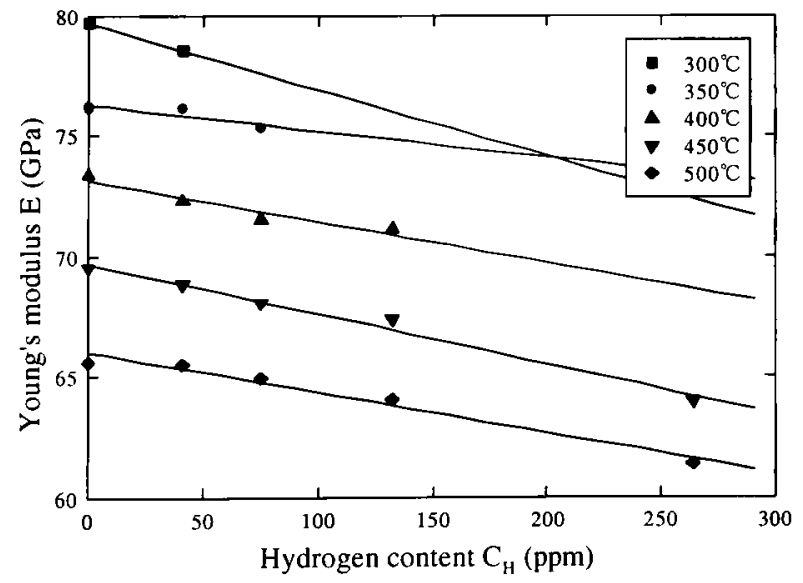

Fig. 8 Change in the Young's modulus $E$ of hydrogen solid solution with the hydrogen content $C_{\mathrm{H}}$

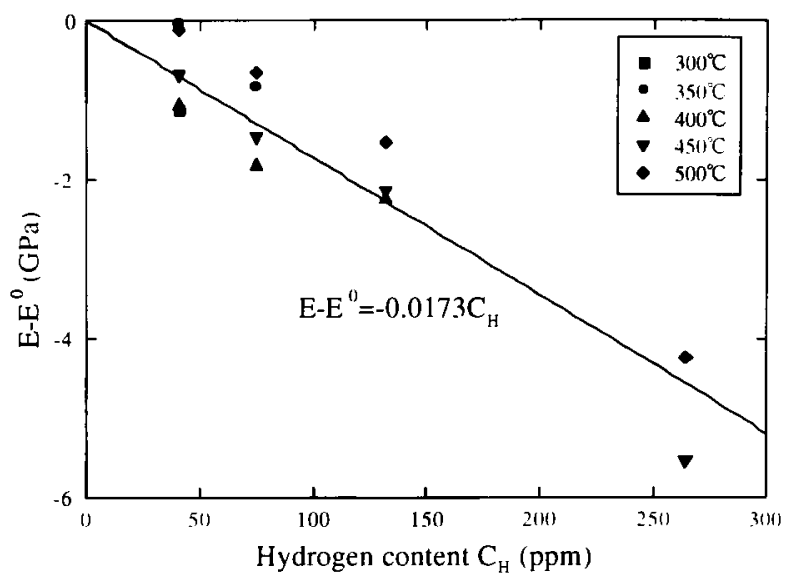

Fig. 9 Change in the parameter $E-E^{0}$ of hydrogen solid solu tion with the hydrogen content $C_{\mathrm{H}}$

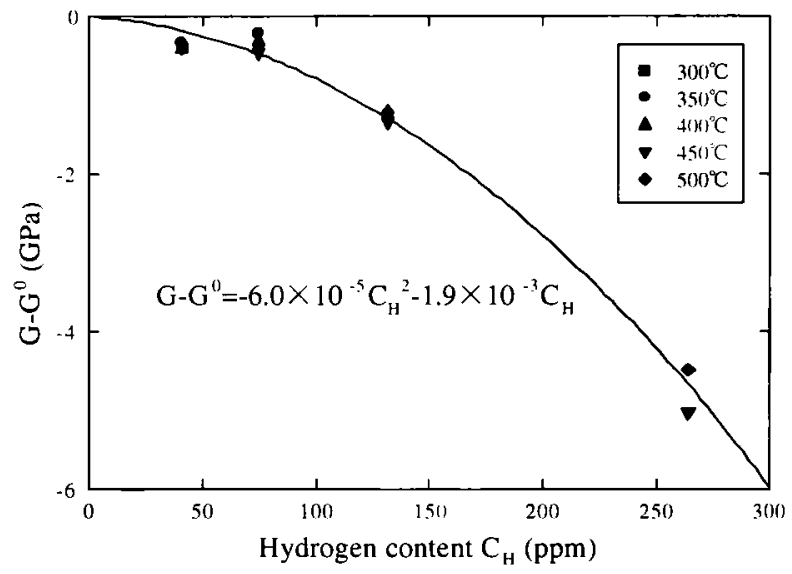

Fig. 10 Change in the parameter $G-G^{0}$ of hydrogen solid solution with the hydrogen content $C_{\mathrm{H}}$

依存せず直線関係が成立していることがわかる。したがっ て，水素固溶体の水素濃度 $C_{\mathrm{H}}$ が増大するのに伴い，ヤン グ率 $E$ が直線的に低下寸る際の傾きに, 温度依存性が存 在しないことが明らかとなった。 $E-E^{0}$ と水素濃度 $C_{\mathrm{H}}$ と の関係は，以下の式で表すことができる。

$$
E-E^{0}=-0.0173 C_{\mathrm{H}}
$$

同様に剛性率 $G$ に関しても，Fig. 10 に測定された剛性 率 $G$ と水素濃度が $0 \mathrm{ppm}$ の際の剛性率 $G^{0}$ との差をとっ たパラメータ $\left(G-G^{0}\right)$ の，水素濃度依存性を示す。同図上 り, $G-G^{0}$ と水素濃度 $C_{\mathrm{H}}$ との関係も, 温度に依存せず以 下の式で表すことができる。

$$
G-G^{0}=-6.0 \times 10^{-5} C_{\mathrm{H}^{2}}-1.9 \times 10^{-3} C_{\mathrm{H}}
$$

ジルコニウム水素固溶体において，水素濃度が增大する のに伴い弾性定数が减少する原因については今後, 電子状 態計算等に基づき，詳細に検討する必要があると考えられ る。 


\section{3. 一部析出水素化物}

室温において，一部析出水素化物の試料のヤング率は， 水素濃度に影響されないとの報告例がある17.18)。しかしな がら本研究では, 先述の Fig. 6 の結果から, 一部析出水 素化物の試料では水素濃度の増大に伴い，ヤング率が若干 增大する傾向のあることを明らかにした。本節では，その ヤング率が若干增大する原因を，前節で報告したバルク水 素化物および水素固溶体のヤング率の結果を用いて検討す る。

一部析出水素化物の試料は，母相が水素固溶体，第二相 がバルク水素化物となっているとみなせる。水素固溶体の ヤング率は，前節で記述したように，水素濃度が増大する のに伴い，若干減少することがわかっている。一方，バル ク水素化物のヤング率は, Fig. $3^{111}$ に示したように, 純 $\mathrm{Zr}$ より大きいことがわかっている。一部析出水素化物のヤン グ率は，その両者の寄与の割合により決定すると考えられ る。Fig. 9 からわかるように，水素固溶体のヤング率が水 素濃度の増大に伴い低下する割合は温度に依存せず，300 $\mathrm{ppm}$ 程度までならたかだか $6 \mathrm{GPa}$ 以内の低下に過ぎ い。一方, Fig. $3^{111}$ から明らかなように, 純 $\mathrm{Zr}$ とバルク 水素化物のヤング率を比較すると，バルク水素化物の方が $40 \mathrm{GPa}$ 程度高い。したがって, 一部析出水素化物のヤン グ率は，水素固溶体の寄与によりヤング率が低下する影響 よりむ，水素化物の寄与によりヤング率が増大する影響の 方が大きいと考えることができる。以上の考察により，一 部析出水素化物のヤング率が，水素濃度の増大に伴い若干 增大する本研究の結果を，定性的に説明することができる。

\section{VI. 結 言}

本研究では, 超音波パルスエコー法, ビッカース硬度試 験, 静的引張試験, 片持ち式固有振動法などの手法によ り, 水素化したジルコニウム $(\mathrm{Zr})$ の音速, 弾性定数, 硬 度, 応力ーひすみ曲線などの様々な機械的性質を評価し, $\mathrm{Zr}$ 合金の機械的性質に及ほす水素吸収の影響を総合的に 検討した。

音速より求めたジルコニウム水素化物のバルク材(バル ク水素化物)の弾性定数は, 純 $\mathrm{Zr}$ よりも高く, 若干水素 濃度に依存した。バク水素化物の微小硬度は, 純 $\mathrm{Zr}$ 上 りも著しく高く，水素濃度の増大に伴い減少した。静的引 張試験によって得られたバルク水素化物のヤング率は，音 速により求めた值と一致した。片持ち式固有振動法により 測定したシルコニウム皮素固溶体の弾性定数は，水素濃度 の増大に伴い低下した。固溶限を越えてジルコニウム皮素 化物が一部析出した試料に対しても，片持ち式固有振動法 により弾性定数が測定され，その結果は，本研究で得られ たバルク水素化物や水素固溶体の弾性定数の実験結果を用 いて，明快に説明することができた。
一参考文献一

1) J. J. Kearns, "Terminal solubility and partitioning of hydrogen in the alpha phase of zirconium, Zircaloy-2 and Zircaloy4", J. Nucl. Mater., 22, 292 (1967).

2）永瀬文久, 大友 隆, 上塚寛, 室温における水素吸收シルカ ロイ-4 燃料被覆管の高速加区バースト試験, JAERIResearch 98-064, 日体子力研究所，(1998).

3）永瀬文久，大友隆，上塚寛，水素添加シルカロ 1-4 然料 被㠅管の $620 \mathrm{~K}$ に抢ける高速加圧バースト試験, JAERIResearch 2000-046, 日本原子力研究所, (2000).

4) M. Kuroda, S. Yamanaka, F. Nagase, H. Uetsuka, “Analysis of the fracture behavior of hydrided fuel cladding by fracture mechanics", Nucl. Eng. Des., 203, 185(2001).

5) S. Yamanaka, M. Kuroda, D. Setoyama, M. Uno, K. Takeda, H. Anada, F. Nagase, H. Uetsuka, "Analysis of the fracture behavior of a hydrided cladding tube at elevated temperatures by fracture mechanics", J. Alloys Comp., 330-332, 400 (2002).

6) M. Kuroda, S. Yamanaka, "Assessment of the combined effects of irradiation and hydrogenation on the fracture behavior of Zircaloy fuel claddings by fracture mechanics", J. Nucl. Sci. Technol., 39[3], 234(2002).

7）日本機械学会編、ジルコニウム合金ハンドブック，日刊工業 新聞社, 東京, 246(1997)。

8）㑑原子力発電技術機構燃料部，平成 12 年度リサイクル然料資 源眝蔵施設安全解析コード改良試験等に関する報告書(燃料 の長期安全性に関する試験)，(2002）.

9) S. Q. Shi, M. P. Puls, "Criteria for fracture initiation at hydrides in zirconium alloys I; Sharp crack tip", J. Nucl. Mater., 208, 232 (1994).

10) S. Q. Shi, M. P. Puls, S. Sagat, "Criteria of fracture initiation at hydrides in zirconium alloys II; Shallow notch", $J$. Nucl. Mater., 208, 243(1994).

11) S. Yamanaka, K. Yoshioka, M. Uno, M. Katsura, H. Anada, T. Matsuda, S. Kobayashi, "Thermal and mechanical properties of zirconium hydride", J. Alloys Comp., 293-295, 23 (1999).

12) S. Yamanaka, K. Yoshioka, M. Uno, M. Katsura, H. Anada, T. Matsuda, S. Kobayashi, "Isotope effects on the physicochemical properties of zirconium hydride", J. Alloys Comp., 293-295, 908 (1999).

13) M. Kuroda, K. Yoshioka, S. Yamanaka, H. Anada, F. Nagase, H. Uestuka, "Influence of precipitated hydride on the fracture behavior of Zircaloy fuel cladding tube", J. Nucl. Sci. Technol., 37, 670(2000).

14) S. Yamanaka, K. Yamada, K. Kurosaki, M. Uno, K. Takeda, H. Anada, T. Matsuda, S. Kobayashi, "Thermal properties of zirconium hydride", J. Nucl. Mater., 294, 94 (2001).

15) K. Tanaka, H. Koguchi, T. Mura, "Dislocation model for hardness indentation problems-II", Int. J. Eng. Sci., 27, 11 (1989).

16）山本悟, 田辺晃生, 新しい材料科学：量子力学に基うくく珫 一的理解, 昭和堂, 京都, (1990).

17) F. Prat, M. Grange, J. Besson, E. Andrieu, "Behavior and rupture of hydrided Zircaloy-4 tubes and sheets", Metall. Trans., 29A, 1643(1998).

18) M. Grange, J. Besson, E. Andrieu, "Anisotropic behavior and rupture of hydrided Zircaloy-4 sheets", Metall. Trans., 31A, $679(2000)$. 